\title{
TAKING OfF The MASks: Dostoevsky SKetChes LifE INTO Fiction
}

\author{
CAMELIA DINU*
}

\begin{abstract}
Starting from the relationship reality-fiction and of theories about autobiography and autofiction developed by Phillippe Lejeune and Phillippe Gasparini, the present study aims to expose the different levels of biographical exploitation in two works published by Dostoevsky in approximately the same period, Notes from the House of the Dead (18601862) and The Gambler (1866), in which the autobiographical material melts into the fiction in different ways. Notes combines elements of autobiography and autofiction, while The Gambler is an example of a fictional text with a powerful autobiographical substrate. In both cases, the strategies used by Dostoevsky to fictionalize his own life aim to distort the real elements of the author's life, in different doses. Dostoevsky constructs for himself a complex fictive identity from a psychological point of view in order to describe his own experiences (the trauma of prison and his obsession with gambling), in a process to remodel the self.
\end{abstract}

Keywords Autobiography, autofiction, fictive journal, trauma of prison, compulsive gambling, narrative distance.

Yuri Lotman proposed that the Russian literature of the second half of the $19^{\text {th }}$ century benefitted from two great life stories, Tolstoy's and Dostoevsky's, "without which it is impossible to understand the work of these writers and the culture of the $19^{\text {th }}$ century in general. ${ }^{1 "}$ If Tolstoy can be considered one of the most autobiographical Russian writers (in the sense that he fictionalized his personal experiences and created numerous alter-egos who reflect his world view and moral vision), Dostoevsky is much more reserved,

\footnotetext{
*University of Bucharest. camelia.dinu@lls.unibuc.ro.

DOI: 10.26424/philobib.2021.26.2.01

1 Yuri Lotman, "Literaturnaja biografija $\mathrm{v}$ istoriko-kul'turnom kontekste (K tipologicheskomu sootnosheniju teksta i lichnosti avtora)" in O russkoj literature: Stat'i i issledovanija (19581993). Istorija russskoj prozy. Teorija literatury (Saint Petersburg: Iskusstvo - SPB, 1997), 816.
} 
autobiographically speaking. Although it is possible to correlate his biography with his writing, that is, to line up events in his life with their metamorphoses in his fiction, Dostoevsky tends to camouflage his authorial voice in favour of a dialogic approach, the polyphonic stance theorized by Mikhail Bakhtin in his famous study Problems of Dostoevsky's Poetics. ${ }^{2}$ In Dostoevsky's fiction, every voice is valid, and the complexity of the discourse arises from the author's vision, which is unsystematic, pluralist, inconsistent and non-transparent.

However, if we are adept at the psychoanalytic or psycho-critical biographic method and insist on looking over the author's shoulder at his work, then Dostoevsky's traumatically eventful life offers generous material for a biographical approach, and we can identify in his fiction echoes of the author's personality. The present study aims to demonstrate various levels of biographical leverage in two of Dostoevsky's works, published in approximately the same time period, Notes from the House of the Dead (18601862) and The Gambler (1866), in which the autobiographic melts in different ways into the fiction. The first work combines elements of autobiography and autofiction, while the second is an example of a fictional text with a powerful autobiographical substrate. In both cases, the strategies employed by Dostoevsky to fictionalize his life aim to distort the actual biographical facts, although to different extents. In both creations, the ego of the text functions as an alternative, a possibility of being the author, although the proportions of the "disguise" and the distance from his personal biography vary.

The present work does not engage with the problematics of auctoriality theorized by Roland Barthes and Michel Foucault in the 1970s. Rather, we are bringing to bear on literary creation the work on autobiography and autofiction offered by theorists such as Phillippe Lejeune and Phillippe Gasparini. Thus, the present study marks a return to the examination of an actual author's life - in the present case, Dostoevsky's - in order to investigate how the author projects himself into textual moments and the degree of distance from the biographical facts. We will investigate the strategies the author uses to both integrate and camouflage his life experiences.

Before examining our two proposed texts, we will identify various aspects of Dostoevsky's biography that will help us follow the relationship between fact and fiction, with an emphasis placed on the authenticity or referentiality of the subject, be he the author, the narrator or the protagonist.

\section{Biographical Mechanisms: The Fictive Journal of Notes from The House of the Dead}

After the success of his debut novel, Poor Folk (1846), Dostoevsky parted company with the literary circle of Vissarion Belinksy, the idealogue of the so-called Natural School of Russian realism, in the wake of this critic's negative evaluation of Dostoevsky's novella, The Double (1846). The young author subsequently frequented

\footnotetext{
${ }^{2}$ Mikhail Bakhtin, Problemy pojetiki Dostoevskogo (Moscow: Sovetskij pisatel', 1963).
} 
the literary circle of Mikhail Petrashevsky, the promotor of the ideal of utopic socialism, where problems related to serfdom, censure, autocracy and corruption were discussed. Accused, along with other members, of "the intention to overturn internal law and the state order," Dostoevsky was arrested and spent eight months at the Peter and Paul Fortress in Saint Petersburg, with a sentence of death by firing squad hanging over him. Once at his execution, he experienced a truly terrifying moment before it was called off at the last minute by the "mercy" of Nicholas I. His punishment was commuted to deportation and hard labour in Siberia, where he spent four terrible years (1850-1854) in Omsk prison. After being released, stripped of both rights and his noble title, he remained under orders not to publish and not to return to Saint Petersburg.

He had to wait until 1857 for his pardon, after which he returned to the capital in 1859 at age 38, having missed a decade of his literary career. After much hesitation, he began to publish Notes from the House of the Dead. From this record of the tsarist prison system in Siberia, transmitted through the voice of a fictive character, the writer received renewed literary validation, as described by American Slavicist Joseph Frank: "No writer was now more celebrated than Dostoevsky, whose name was surrounded with the halo of his former suffering, and whose sketches only served to enhance his prestige as a precursor on the path of political martyrdom. ${ }^{3 \prime}$ The unusual intrigue - the life of a nobleman condemned to a Siberian prison became a sensational literary event at the time and laid the groundwork for Russian concentration camp literature.

During his time in the prison hospital (1844-45), the author began sketches in his so-called Siberian Notebook, ${ }^{4}$ which laid the groundwork for his Notes. Four years later, namely in October 1859, he wrote a letter to his brother, Mikhail, in which he recorded his intention to write a new novel:

\begin{abstract}
"In December I will start a novel (but not the one about a young man who was brutalized and ended up in Siberia.) No. You remember, I told you about a Confessions - a novel I've been wanting to write for some time, telling myself that I should get going on it. These past few days I've decided to write it immediately. It will be, first, spectacular and passionate and, second, my whole heart, with its blood, is based on this novel. I conceived of it with great effort, stretched out on my prison cot, in a difficult moment of sadness and personal unraveling. ${ }^{5 \prime \prime}$
\end{abstract}

\footnotetext{
${ }^{3}$ Joseph Frank, Dostoevsky: The Stir of Liberation (Princeton: Princeton University Press, 1988), 140.

${ }^{4}$ The notebook contains about 500 notes about life in the prison in Omsk.

${ }^{5}$ Pis'ma Dostoevskogo [Dostoevsky's letters],

http://dostoevskiy-lit.ru/dostoevskiy/pisma-dostoevskogo/dostoevskij-dostoevskomu-9oktyabrya-1859.htm (Accessed in May 2021).
} 
After his release from the Siberian prison, the former political detainee hesitated almost eight years to publish his "remembrances." Most probably, he opted for a fictional "adaptation" of his personal experiences for two reasons: i) the large temporal gap between his lived experience of prison and the moment of writing his prison "journal"; and ii) the trick of avoiding censure for any possibly uncomfortable passages. ${ }^{6}$

In Notes, there are two narrators. The first anonymous editor appears in the introduction and prepares the publication of the memoirs. The second, named Aleksandr Petrovich Gorianchikov, is the fictive author of the memoirs who experienced the events and recorded them in the form of a prison journal. He is a nobleman aged 35, condemned to ten years of hard labour in Siberia for having killed his wife in a fit of jealousy. He confesses to his crime and surrenders to the authorities. After completing his sentence, he cuts off relations with his relatives and settles down in a Siberian town where he pursues an isolated life and lives off giving private lessons. Three years later, he dies. The anonymous editor finds Gorianchikov's records after this fictive author's death.

The editor gets to know Gorianchikov shortly before his death and interacts with him sporadically but insistently, however much Gorianchikov tries to avoid him. Rather indiscreetly, the editor later asks the deceased's housekeeper for the papers with the title Scenes from a Dead House and proposes to offer several chapters to the public, as a kind of test: "Of course, I may be mistaken. I will begin by selecting two or three chapters; let the public judge..." His initial intention, that of revealing only several chapters, is tacitly exceeded, and the work is published in two parts, with 10 and 11 chapters respectively. After the fictive editor introduces the work, he disappears, only to reappear one more time in Chapter VIII, Part II, where he clarifies the situation of a parricidal detainee from the ranks of the nobility. For the rest, the focus of the narrative is transferred exclusively to Gorianchikov, who tells his story in the first person.

The relationship between autobiography and fiction in Notes is problematic, making Dostoevsky's work difficult to categorize. Here, Lejeune's work helps to pinpoint the difficulty. On the one hand, the text respects the traits to which Lejeune attributes the autobiographical genre: "Retrospective prose narrative written by a real person concerning his own existence, where the focus is his individual life, in

6 "This fictionalizing was in part a mask for the censors: the notes of a man serving a sentence for a common-law crime were more likely to be passed for publication than the notes of a political criminal." (Richard Pevear, "Foreword," in Fyodor Dostoevsky, Notes from a Dead House, transl. Richard Pevear and Larissa Volokhonsky, with an introduction by Richard Pevear (New York: Alfred A. Knopf, 2015), 14).

7 Fyodor Dostoevsky, Notes from a Dead House, transl. Richard Pevear and Larissa Volokhonsky, with an introduction by Richard Pevear (New York: Alfred A. Knopf, 2015), 24. 
particular the story of his personality." And: "The subject of an autobiographical text is the past history of its author. Yet autobiographical writing is itself part of this history, and in fact is often represented in the text itself. ${ }^{9 \prime}$ Without a doubt, Dostoevsky's text exhibits the four traits identified by Lejeune that define an autobiography: "i) form of language (narrative, in prose); ii) subject treated (individual life, story of a personality); iii) the situation of the author and the narrator are identical; and iv) the position of the narrator (the narrator and the principal character are identical; retrospective point of view of the narrative. ${ }^{10 \prime}$ To these, Lejeune adds other elements: "The perspective is mainly retrospective; this does not exclude some sections from taking the form of the self-portrait, a journal of the work or of the contemporary present of the composition, and some very complex temporal structures. ${ }^{11 \prime \prime}$

On the other hand, Dostoevsky's text contains numerous elements that demonstrate the fictionalization of the autobiographical material. The swing between authentic biography and creative fiction, between personal involvement and authorial distancing, between objectivity and subjectivity is a fundamental trait of Notes. For example, although Dostoevsky proposes to diminish the maximum level of intimacy from the text ("My personality will disappear from view. These are the notes of an unknown man. ${ }^{12 ")}$, he only partly accomplishes this wish: he chooses the narrative form of a quasi-fictive journal of someone else and avoids the conditions of autobiography, in the sense that the discourse does not offer an identity between the first-person narrator and that of the author. However, despite the author's efforts at camouflage, the public received Notes as an unmediated confession by the author. Dostoevsky was unhappy with this unidirectional perspective: the public ignored the artistic dimension and the moral-philosophical problematic in favour of the living, realistic fact, of autobiographical authenticity. It is true that several inaccuracies in the text lead the reader to ignore the artifices of fiction: although in the Introduction it is said that Gorianchikov is condemned for a crime of passion, this charge is never mentioned again. Moreover, in Chapter II, Part $\mathrm{I}$, it is suggested that the detainee is a political prisoner - which was, in fact, the case for Dostoevsky.

These inexactitudes diminish the effect of distancing, while Gorianchikov fades by degrees in favour of the actual author himself. It seems that, after a certain

\footnotetext{
8 Phillipe Lejeune, On Autobiography, ed. Paul John Eakin, trans. Katherine Leary (Minneapolis: University of Minnesota Press, 1989), 4.

9 Philippe Lejeune, On diary, ed. Jeremy D. Popkin \& Julie Rak, trans. Katherine Durnin (Honolulu: University of Hawai'i Press), 214.

10 Phillipe Lejeune, On Autobiography..., 4.

11 Ibid., 5.

12 Pis'ma Dostoevskogo [Dostoevsky's letters], http://dostoevskiy-lit.ru/dostoevskiy/pismadostoevskogo/dostoevskij-dostoevskomu-9-oktyabrya-1859.htm_(Accessed in May 2021).
} 
point, the actual author forgets to mask his narrative, from the fictional and conventional Gorianchikov and assumes, in the end, the related facts for himself. As theorist and translator Richard Pevear explains: "Dostoevsky's personality does not disappear from view; he is present as the observer of the life around him, but also as the protagonist of the inner transformation that the experience of prison brings about in him. ${ }^{13 "}$ From this perspective, the text is much closer to a document and factography and, despite all the preoccupation with distancing, it seems that Dostoevsky himself speaks about the most important moments in his life as a detainee.

Although Gorianchikov's voice is convincingly constructed from a fictional point of view, Dostoevsky's voice does at times come through. For instance, Escape (Chapter IX, Part II) contains a confession that we must attribute to the actual author. He recognizes, shoulder to shoulder, with Gorianchikov the immense volume of information, portraits and life experiences and even the (im)morality that the prison experience provided him:

"Must I make note of all that life, of all my years in prison? I don't think so. If I were to write out in order, in sequence, all that happened and that I saw and experienced in those years, I could, naturally, write three or four times more chapters than I have written so far... I wanted to present the whole of our prison and all that I lived through during those years in one graphic and vivid picture. Whether I have achieved that goal, I don't know. And that is not entirely for me to judge. But I'm convinced that I can stop here. ${ }^{14 \prime \prime}$

Not by chance do we observe both the similarity between Gorianchikov's voice in Notes and Dostoevsky's voice in the comment he writes to his brother in a letter:

\footnotetext{
"What a number of national types and characters I became familiar with in prison! I lived with them and that is why, it seems, I know them sufficiently well. How many stories... It's enough for a whole volume. What a marvellous people. Generally speaking, the time wasn't wasted for me. ${ }^{15 \prime \prime}$
}

\footnotetext{
${ }^{13}$ Richard Pevear, "Foreword"..., 14.

${ }^{14}$ Fyodor Dostoevsky, Notes from a Dead House..., 295.

15 Pis'ma Dostoevskogo [Dostoevsky's letters],

http://dostoevskiy-lit.ru/dostoevskiy/pisma-dostoevskogo/dostoevskij-dostoevskomu-9oktyabrya-1859.htm_(Accessed in May 2021).
} 
At other times, in Notes, Gorianchikov speaks of the monotony of the years spent in the prison and demonstrates how all his energy was focused on his release. His memory of this time becomes very subjective:

"I myself sometimes get sick at heart from these memories. And I can hardly remember everything. The subsequent years have somehow been erased from my memory. I've completely forgotten many circumstances, I'm sure of that. I remember, for instance, that all those years, essentially so like one another, went by sluggishly, drearily. I remember that those long, boring days were as monotonous as rainwater dripping from the roof drop by drop. I remember that only the passionate desire for resurrection, renewal, a new life, gave me the strength to wait and hope. ${ }^{16 \prime}$

In numerous metatextual passages such as the one above, Gorianchikov alias Dostoevsky justifies the delay in publishing his memoirs and recognizes that the distance of time from the moment of his prison experiences makes them "vulnerable" to fiction.

Czech Slavicist Tomáš Masaryk reveals the importance of the principal events from Dostoevsky's life transposed into fiction. This researcher considers that Notes plays an important role in the transfiguring of the author's life story and distancing it from the real person. ${ }^{17}$ In his analysis, Masaryk correlates the relationship author-narrator-character by a complex psychological process of empathy, in which regard, according to the Czech scholar, Dostoevsky is a master. Thus, Masaryk considers Notes to be very expressive from the point of view of projection (in the sense of a mirror) in constituting the other: ${ }^{18}$ more exactly, isolation from the exterior world determines the search for one's own soul in others. This role of distancing is found without a doubt in the technique of the manuscript and in the stories within the stories used by Dostoevsky in Notes. He starts from the lived moments in prison and reformulates the story of his own experience into a fictional moment. Literary scholar Oleg Kovalyov speaks about the tendency to auto-mythologize which occurs in the Dostoevskian discourse in Notes and which favours several thematic options and narrative characteristics for the author's style:

\footnotetext{
${ }^{16}$ Fyodor Dostoevsky, Notes from a Dead House..., 296.

17 Tomáš Masaryk, "Sochinenija Fjodora Mihajlovicha Dostoevskogo", vol 1: "Zapiski iz Mjortvogo doma" in Dostoevskij. Materialy i issledovanija, ed. G.M. Friedlender, vol. 18 (St Petersburg: Nauka, 2007), 201.

18 Ibid., 201-202.
} 


\begin{abstract}
"The narrative representation of Dostoevsky's biography consolidates several key elements, which marks the crossing of a new stage in the ideological evolution of the writers - from the Occidentalism of the $1840 \mathrm{~s}$ to a Slavophile position (Pochvennichestvo ${ }^{19}$ ) in the interval 1860-1870. Two factors in particular contributed to the limits of these two periods: Before and After. The first - Dostoevsky's condemnation in 1849 followed by his exclusion from literary life; the second - the reform at the beginning of the 1860s, perceived by the author as the start of a fundamentally new period in Russian history. The gap between these two biographical segments, intensified during his stay at the House of the Dead, activated certain mythological models which determined not only the modalities of narrativizing his own life but also the process of generating themes and artistic motifs: peace, crime, redemption, sacrifice, death and rebirth. ${ }^{20 \prime}$
\end{abstract}

Notes has a forthright and paradoxical quality - one that both validates and successively annuls the presumption of autobiography. This work is a result of the strategies Dostoevsky uses to create a connection between the real and the literary and to construct for himself, at different levels and in different doses, his fictive identity.

\title{
Fictionalizing Mechanisms: Discursive Strategies in Notes from the House of the Dead
}

In the complex process of fictionalizing autobiographical material Dostoevsky does not avoid subterfuge and plays of imagination. The motif of the "found manuscript," which generates in Notes the technique of mise en abyme, as well as the artifice of the narrator Gorianchikov, are both fictionalizing strategies.

We can consider Notes as autofiction, using a concept proposed more than one hundred years after the publication of Notes by theorist Serge Doubrovsky, ${ }^{21}$ in 1977 , and further nuanced by numerous other scholars. In this sense, as an autofictional text, Notes begins with a real person in order to create a character through fictionalization. Unlike autobiography, which respects the identity relationship between narrator, character and author, in Notes the character is an alter-ego of the

\footnotetext{
${ }^{19}$ A literary, social and philosophical direction in Russia in the 1860 s with a conservative and neo-slavophilic orientation.

20 Oleg Kovalyov, Narrativnye strategii v tvorchestve F.M. Dostoevskogo (Barnaul: Izdatel'stvo Altajskogo gosudarstvennogo universiteta, 2011), 209.

${ }^{21}$ Serge Doubrovsky demonstrated the possibility of hybrid forms which tie reality to fiction through autofiction, a genre between fiction and autobiography in which the author, protagonist, and narrator share one identity.
} 
author (the author's name and the character's name are different). Or to say it better, the character is the author himself but imagined in the light of fiction. Combining autobiography and fiction, Dostoevsky uses several fictive intrigues and imagines scenes which start from the "character" in real life. According to Gasparini's theory of autofiction, ${ }^{22}$ this literary form must fulfil a variety of criteria, among which Notes respects: a dominant narrative through-line, an original form of organizing the discourse, a deformation of linear order and chronology (fragments, involuntary memories). Other criteria cited by Gasparini are not however fulfilled: there is no identity of name between the author and the narrator, the work does not carry the subtitle "Novel", and the use of the present tense does not dominate.

Gorianchikov is a conventional character who crosses over from autobiography to fiction and assures a fusion of Dostoevsky with his hero - we refer surely to the ideological fusion but most especially the psychological. From this perspective, Notes contains numerous elements of psychological prose, which reflect the disarticulation of the interior world, a crisis of the soul, the breaking point. The narrator is absorbed by the exceptional manifestations of the human psyche, by extreme emotions and experiences.

Dostoevsky at once constructs and destabilizes Gorianchikov's psychology through a mix of interior monologue and involuntary memories. Gorianchikov oscillates between the hypostasis of the subjective narrator who remembers the past and the character-actor: "I remember my first morning in the barrack. ${ }^{23 "}$ "I remember very well. ${ }^{24 " ~ " I ~ r e m e m b e r ~ e v e r y t h i n g ~ t o ~ t h e ~ l a s t ~}$ detail. 25 " "I remember only one thing, that it was not out of idle curiosity. ${ }^{26 " ~ " I ~}$ remember how I would sometimes look greedily through the chinks in the paling and stand for a long time. ${ }^{27 \prime \prime}$ This play between past and present, that is, the relationship between psychological and chronological time, creates a state of tension in the interior of the character. Overall, the narration is predominantly ulterior, a post-hoc narrative act: "This was long ago now; I see it all as if in a dream. I remember how I entered the prison. It was on an evening in the month of December. ${ }^{28 \prime}$ Many times, it seems that the discourse is no longer retrospective:

\footnotetext{
22 Philippe Gasparini, Autofiction: Une aventure du langage (Paris: Éditions du Seuil, 2008), 209.

${ }^{23}$ Fyodor Dostoevsky, Notes from a Dead House..., 40.

24 Ibid., 100.

25 Ibid., 101.

26 Ibid., 210.

27 Ibid., 238.

28 Ibid., 28.
} 


\begin{abstract}
"But why describe this muddle! The stifling day is finally over. The prisoners fall into heavy sleep on their bunks. In their sleep they talk and rave even more than on other nights. Here and there people still sit at the maidans. The long-awaited feast is over. Tomorrow is an ordinary day again and work again. ${ }^{29 \prime \prime}$
\end{abstract}

As we see here, the discourse is constructed in the present tense, simultaneous with the moment of action.

The voice in Gorianchikov's memories signals a veritable representation of a Russian aristocrat, a cultivated person, a reflexive and sensitive spirit, an excellent observer, a well-focused raisonneur. The way in which he self-analyses from a psychological point of view confers on the exposition an impressive authenticity. Natalya Kozhevnikova identifies a general evolution in the narrator in Dostoevsky's work as a displacement of the first-person narrator toward an omniscient narrator "who enters the point of view of the character" and then aims toward "a complex synthesis of various oppositive narrative forms. ${ }^{30 "}$ In the framework of this complex process of narrative distancing, Notes occupies a transitory position, functioning, on the one hand, to give the interior monologue back to Gorianchikov and, on the other hand, to frame him as a character in a narrative where he is spoken of in the third person. A pertinent explanation in this direction is offered by Elena Akelkina: "In many cases, the narrator's discourse interacts with the impersonal voices which contribute to the formation of his vision of the world. In this sense, Gorianchikov becomes the subject and the object of the narration. ${ }^{31 "}$ Dostoevsky does not exploit his own journal but rather decides to relate his experiences through the intermediary of a character who speaks in the first person. As Kovalyov shows, "Dostoevsky's search for a recipient of his work and the hero's search for a recipient of his are fundamentally interconnected. ${ }^{32 "}$ In other words, Dostoevsky does not speak in his own voice but rather empowers a character - one who feels the need to confess - to tell the story of the experiences of the author who created him.

Furthermore, the first anonymous narrator confirms from the very beginning the diaristic character of the text and validates Gorianchikov's subject perspective:

\footnotetext{
29 Ibid., 161.

30 Natalya Kozhevnikova, "O sootnoshenii tipov povestvovanija v hudozhestvennyh tekstah", Voprosy jazykoznanija, 4 (1985), 110.

${ }^{31}$ Elena Akelkina, "Zapiski iz Mjortvogo doma" in Dostoevskij: Sochinenija, pis'ma, dokumenty: Slovar'-spravochnik, ed. G.K. Shhennikov (St Petersburg: Pushkinskij dom, 2008), 73.

32 Oleg Kovalyov, "Tvorchestvo kak ispoved': situacija ispovedi v proizvedenijah F.M. Dostoevskogo", Izvestija Altajskogo gosudarstvennogo universiteta, vol. 2, 2 (2011), 150.
} 
"I took his papers and spent the whole day sorting them. Threequarters of these papers were empty, insignificant scraps, or his pupils' exercises in penmanship. But there was one notebook, a rather voluminous one, filled with small handwriting and unfinished, perhaps abandoned and forgotten by the author himself. It was a description, though a disjointed one, of the ten years of life at hard labor that Alexander Petrovich had endured... But the notes on hard labor - "Scenes from a Dead House», as he himself calls them somewhere in his manuscript - seemed to me not without interest. The totally new world, unknown until then, the strangeness of some facts, certain particular observations about those lost people, fascinated me, and I read some of it with curiosity. Of course, I may be mistaken. As a test, I will begin by selecting two or three chapters; let the public judge.... ${ }^{3 \prime \prime}$

The dynamics of prison life leave their indelible mark on Gorianchikov: the conflicts among the detainees, the work program, trades practiced as both obligations and free choices, the atmosphere of the kitchen, the public bath, the revolts, hospital life, corporal punishments and their psychic impact on the victims, the executioner, distractions, religious celebrations in the prison, escapes.

After his release from prison, Gorianchikov avoids other people and continues the social strategy he devised while incarcerated. From a convict inside a prison, he becomes a self-imposed convict in his outside life. The only dose of liberty he has transpires in the way he writes his memories at night. Only in this space, of remembering, in this exercise of (auto)witnessing, is he relaxed and balanced. However, even here, beyond any concessive attitude, the experience of prison is presented as an absolute negative. Here and there Gorianchikov seems indifferent, resigned, a man whom nothing surprises anymore. In fact, his journal is an attempt to recover from trauma through confession. The American Slavicist Robert Louis Jackson interprets Gorianchikov's death allegorically, as the expression of the author's personal crisis and constitution of his beliefs during his incarceration. The death of the character signifies the liberation of the author from old conceptions and a spiritual rebirth. Confronting both author and characters, Jackson considers that Notes is a double journey in exile, as the experience of auto-transcendence. ${ }^{34}$ Thus, Dostoevsky's future plans are put in Gorianchikov's mouth: "I outlined a program for the whole of my future and resolved to follow it firmly. A blind faith arose in me that

\footnotetext{
33 Fyodor Dostoevsky, Notes from a Dead House..., 24.

34 Robert Louis Jackson, The Art of Dostoevsky: Deliriums and Nocturnes (Princeton NJ: Princeton University Press, 1981), Russian edition Iskusstvo Dostoevskogo: Bredy i noktjurny (Moscow: Radix, 1998), 14.
} 
I would and could fulfil it all .... I waited, I called for freedom to come quickly; I wanted to test myself news, in a new struggle. ${ }^{35 "}$ Although Dostoevsky never wants to fully put down his mask, he betrays many well-known elements of his biography, seen in affirmations of the type: "I had entered prison in winter and therefore in winter I was also to be set free, on the same day of the month as I had arrived. ${ }^{36 "}$ We know from Dostoevsky's biography that he entered the prison in Omsk in winter, January 1850, and was released similarly in winter, February 1854.

Gorianchikov's story does not have a unitary subject and, instead, constitutes itself in the form of a micro-narration which has as its matrix a portrait. Although the mnemonic contents are organized rather by affective principles, the effect is nevertheless not accidental and variable. In the first part, the journal respects a chronology (First Impressions I, II, III, The First Month I, II), after which the attention of the diarist is concentrated on portraits of his fellow detainees, while the temporal references are much more flexible. Through Gorianchikov's eyes, we see in detail the daily life and habits of the prisoners, the relationships among them, their moral and religious conceptions, more precisely: how they obtain through contraband money, vodka, tobacco, better food, better clothing, how they amuse themselves, their relationships with the administration, their attitudes about work, what is forbidden and what is allowed, how to steal, the punishments, what food they receive from the outside. Dostoevsky, seconded by Gorianchikov, offers dozens of portraits, some only sketches and anonymous, others well individualized, presented in detail. They form one long continuous chain, linked by a formula of the type: "But I'll speak of the rules later." "I cannot help saying a few words about him, though it takes me away from my subject." "But I've strayed from my subject." These formulae confer a cursive character to the text which accentuates the suspense.

What transpires is a collective portrait of the approximately 250 prison workers, classified by diverse criteria: social category, type of prison sentence, preferred trade, "inside" or "outside", behaviour, moral features. The abundance of portraiture is overwhelming, the general impression is that of homogeneity, most probably because the principles of individual presentation were respected (physical and moral portrait, realized in general through physiognomy, the history of the condemned, relationship to the narrator). This "totally new world" is one of refracted biographical elements that shift between social fresco, soap opera, and prison folklore. Notes transposes contexts, currents of ideas, the social-political climate of Dostoevsky's time.

The solutions Dostoevsky found in Notes to camouflage his own biography include: the pretext of a found manuscript, segmentation in chapters, the dissociation of the author-narrator-character, the refusal to expose his interior by crossing sporadically into third-person narration, dialogue, access to the subjectivity

\footnotetext{
${ }^{35}$ Fyodor Dostoevsky, Notes from a Dead House..., 296.

36 Ibid., 309.
} 
of his characters. The possibility of the identity between author-narrator-character, the relationship with real and verifiable persons and places, invested in Dostoevsky's letters and manuscripts confer on the text autobiographical accents. This is a text that can well be included in the category of autofiction, in which the character resembles - at least at a distance - the author himself. Several of the characters from the "House of the Dead" will have a future in Dostoevsky's later creations, and they will be memorable. Famous Dostoevskian characters - among whom Dmitri Karamazov from The Brothers Karamazov and Arkady Svidrigailov from Crime and Punishment - have as prototypes the real people with whom Dostoevsky interacted in prison before they turned up in his great novels.

Integrating his personal experience into fiction, Dostoevsky reimagines and reinvents as much the story of an individual's life as the story of a community and of a society. The author's phantasm is often blurred, and the result is a social and moral document of the era. Predominant is the tonality of confession. Thanks to its philosophical basis, Notes also has an important aesthetic character which contributes to the constitution of distinct Dostoevkian voices, which will become fully realized in the major novels of the following period.

\title{
The Fictionalization of an Obsession: The Gambler
}

While in Notes the autobiographical component may be easier to ferret out, the novel The Gambler represents a more subtle level of biographical fictionalizing. In this case, the aesthetic intention comes into the foreground, while the facts of the essential biography are significantly modified. The emphasis no longer falls, as it does in Notes, on that which is told but rather how it is told. Although even here the novel has an undeniable autobiographical nucleus.

The idea for the novel was born in the fall of 1863. In September, in Rome, Dostoevsky wrote to the critic and publicist Nikolay Strakhov and described to him the prototype of the main character:

\begin{abstract}
"The real idea, though, lies in his having wasted all his substance, energies, and talents on roulette. He is a gambler, but no common gambler, just as the "miserly knight» of Pushkin is no common miser. (I don't in the least mean to compare myself to Pushkin. I only use the comparison for lucidity's sake.) He is in his way a poet, yet he is ashamed of such poetry, for he feels profoundly its vulgarity, even though the longing for touch-and-go ennobles him in his own eyes. The whole story is concerned with his playing roulette for full three years. ${ }^{37 \prime \prime}$
\end{abstract}

37 Pis'ma Dostoevskogo [Dostoevsky's letters], 
In this letter, Dostoevsky compares the new work to Notes, anticipating an even bigger success for the new novel with the public:

"If my «Dead House» - as a picture of prison, which no one before me had thus psychologically displayed - greatly interested the public, the new story, as a psychological and faithful portrait of the roulette-player, will interest them still more. ${ }^{38 \prime}$

Three years later, Dostoevsky wrote The Gambler under difficult conditions, being himself seriously addicted to games of chance.

What led to this obsession? Shortly before his return to Saint Petersburg from his deportation in 1859, Dostoevsky had abandoned games of chance and stayed "out of the action" until 1871 (in his youth, he had played billiards and squandered quite a lot of money, but roulette had driven him crazy). In order to receive money in advance (with which either he paid off some of his debts or he returned to the roulette table), the author signed disadvantageous contracts with his editors, with the risk of losing his royalties and of having to pay significant damages. In 1866, overwhelmed by debt, he contracted to write a novel for the editor Fyodor Stellovsky, with the clause that in case of failure to deliver by the due date, his royalties would revert to the editor for a period of nine years. He hired a young stenographer, Anna Grigorevna, and succeeded in writing The Gambler in 26 days and delivering it on time.

Dostoevsky lived from his writing and wrote for the most part under pressure from creditors. With his advance monies for The Gambler he paid off his debts (as he did with his advance for Crime and Punishment). His gambling failures, his naivete and credulity led to his creditors hounding him for years on end. Even the devoted Anna Grigorevna, after she married him, could not control his monetary extravagances, and the married couple remained under constant threat of bankruptcy and pressing poverty generated by the loss of great sums of money at roulette. The Gambler is a novel written under contract and reflects the vices that partially ruined the author's life, namely cards and roulette. Dostoevsky fictionalized his own pathological dependence on games of chance. Through the voice of the primary character, the author expresses his own theories about gaming. In this sense, Ljudmila Saraskina underlines the biographical nature of the novel:

http://dostoevskiy-lit.ru/dostoevskiy/pisma-dostoevskogo/dostoevskij-strahovu-18-30sentyabrya-1863.htm_(Accessed in May 2021).

38 Ibid. 


\begin{abstract}
"The Gambler became a novel-game in which the writer-gambler not only empathized with the hero-gambler but also gambled right along with him. Both are obsessed by this passion, both know the insidious temptation of the game that can change destiny .... A total monomania. The story from the first-person perspective of the gambler is tightly bound to the author's own perspective. ${ }^{39 \prime \prime}$
\end{abstract}

In a monograph dedicated to Dostoevsky, Norwegian Slavicist Peter Normann Waage follows the path taken by the author from the glorification of his idols to their demolition, as in life, so in his works (the researcher insists on the way in which the circumstances of life are projected into fiction). One of the idols Waage discuses is precisely card games. ${ }^{40}$

As he did in Notes, Dostoevsky chooses the handiest form to fictionalize his own experience: the fictional journal. Thus, The Gambler is written in the form of recollections of a young preceptor (uchitel'), Aleksei Ivanovich. This young man, a noble and possibly a student, is hired by an army general, a widower, to take care of the general's two children. The family and Aleksei leave Russia and travel to Germany, where they settle in the town of Ruletenburg. As it happens, Aleksei has fallen in love with the general's stepdaughter. The basis of the romantic intrigue rests in Dostoevsky's own complicated relationship with the much younger Apollinaria Suslova who would become the prototype of the character Polina Aleksandrovna - one of Dostoevsky's infernal heroines. Just as Notes contains the prototypes of some of Dostoevsky's most famous heroes, so The Gambler offers the forerunners of remarkable heroines.

The gambler's journal has 17 chapters which respect the conventions of the diaristic genre: its fragmentary character, the spontaneity of actions and records, the lapidary exposition. The notes from the journal represent for the possessor an instrument of self-understanding and acts as a confidant, a space of refuge. Through these records, the narrator constructs his self-image and undertakes an analysis of the self and of the relations between interior/exterior and identity/alterity. The narrator-character has the typical portrait of a diarist, consumed by hesitation, erotic unfulfillment, loneliness, nostalgia. Overall, we have here a crisis journal through the intentions of liberatory confessions and a journal of meditation through sententious observations and reflections that it includes.

\footnotetext{
${ }^{39}$ Ljudmila Saraskina, Dostoevskij v sozvuchijah i pritjazhenijah (ot Pushkina do Solzhenitsyna) (Moscow: Russkij put', 2006), 188-189.

40 Peter Normann Waage, Fjodor M. Dostojevskij (Oslo: Gyldendal, 1997), russian edition Fjodor Dostoevskij: sverzhenie idolov (St Petersburg: Knigoizdatel'stvo "Vsemirnoe slovo", 2003).
} 
The protagonist is a subjectively unreliable narrator, and this status determines the sensation of ambiguity, indetermination, and fragmentation in the text. Like Gorianchikov in Notes Aleksei oscillates between two hypostases, the subjective narrator (who recalls the events experienced in Ruletenburg) and the character-actor, suggested by the oft-repeated formula: "I remember how..." However, in contrast to Notes, The Gambler has a higher level of fictionalization. The novel contains an erotic intrigue, elements of a Bildungsroman, and creates an ample image of life with profound social implications. It also includes an imagologic component with portraits and cultural stereotypes appear of Russians, French, Germans, Poles, English. In addition, Moscovites are pitted against ex-pat Russians, both of which are contrasted with their Occidental counterparts - and here we guess the neo-Slavic attitude of the actual author, as shown by Russian researcher Sergei Schulz: "Dostoevsky correlates the image of the protagonist with the theme of Russians and Russia, as is well known, the motif of "national types" is fundamental in the novel rather than individual characters. ${ }^{41 "}$ While in Notes Dostoevsky distances himself only intermittently with his actual biology, in The Gambler the distancing is constant and continuous.

The Gambler fully exploits elements specific to adventure novels. Schulz shows that this prose occupies a separate space in Dostoevsky's work: the level of exterior narration dominates the subject of the adventure novel; characters and subjects are constructed with a higher grade of conventionality and schematization. At the same time the author introduces into this frame a psychological complex content. ${ }^{42}$ Why does Aleksei write in his journal? For his two passions: Polina and roulette. Eventually his passion for roulette surpasses his passion for Polina. As Schulz explains, "For Dostoevsky the spirit of adventure is bipolar: on the one hand, it is associated with love, on the other hand it is presented through the topos of the game. ${ }^{4 \prime \prime}$ Thus, the writer inserts into the structure of an adventure novel psychological elements which are unusually expressive and veridical exactly due to the fact that the real-life author is describing his own gambling pathology with all the symptoms: loss of impulse control, negative consequences in his life and of the lives of those around him, difficulties in social relationship, obsession to recoup his losses, reckless borrowings.

Another biographic element dissolved into the novel represents Dostoevsky' travels outside Russia. Dostoevsky managed to visit European cities not in order to treat his epilepsy, as officially announced, but rather to frequent the casinos and to escape the harassment of his creditors in Russia. In all, Dostoevsky

${ }^{41}$ Sergei Schulz, "Igrok Dostoevskogo i Manon Lescaut Prevost (Aspekt istoricheskoj pojetiki)," Russkaja literatura, 3 (2004), 160-164: http://az.lib.ru/d/dostoewskij_f_m/text_0790.shtml (Accessed in June 2021).

$42 \mathrm{lbid}$.

$43 \mathrm{lbid}$. 
travelled to Europe eight times and lived abroad about five and half years, visiting Germany, England, France, Austria, Italy, Switzerland, among other countries.

Overall, the novel represents a monograph of playing roulette, which contributes to the analysis of the experience and the behaviour of gamblers and the dynamics of the gambling setting. The first-person narration is valorised by the narrative form of the journal (Dostoevsky uses the convention of first-person narration to intensify the effect of authenticity.) The novel develops the themes of risk and of gambling as well as adjacent problems: destiny and its mysteries, choice, spiritual liberation and its limits, life and death as a game of roulette. Dostoevsky knows this thematic territory very well because he lived it.

Analysing Notes from the House of the Dead and The Gambler we have observed that the projection of the actual writer's life into a textual moment and the interweaving between documentary/autobiographic elements with imaginary ones generated two original creations with the theme of suffering and psychological vulnerability. Starting with the life story of the actual author we have analysed the ways in which he chooses as a textual mask, and we have delimited the different grades of self-insertion into his fiction. Dostoevsky constructs for himself a complex fictive identity from the psychological point of view in order to describe his own experiences (the trauma of the prison, his obsession with gambling) in a complex process of remodelling himself and of distancing himself (from his traumatic experiences). In both works under review the autobiographical component is recognizable in many areas and included in the narration in different doses. Dostoevsky implicitly realizes a generic experiment by putting in evidence the convention and limits of fiction as well as nonfiction in the frame of the same text. He uses fiction to illuminate his real experience, while the identification of biographic echoes in Dostoevsky's fictional works - or, in other words, the resuscitation of his biography - facilitates a more profound understanding of the author's personality and the dynamics of his work. 
This work is licensed under a Creative Commons Attribution 4.0 International License 